УДК 614.31:635:546.8

DOI: $10.36461 / N P .2019 .52 .3 .002$

\title{
О СОДЕРЖАНИИ КАДМИЯ В ДИКОРАСТУЩИХ КОРМОВЫХ, ЛЕКАРСТВЕННЫХ И ПИЩЕВЫХ РАСТЕНИЯХ ЛЕСОВ ПЕНЗЕНСКОЙ ОБЛАСТИ
}

\author{
А. И. Иванов, доктор биол. наук, профрессор
}

Пензенский государственный аграрный университет, Россия, т. 896563331761. e-mail: rcgkim@mail.ru

\section{М. И. Андреева, научный сотрудник}

Филиал фредерального бюджетного учреждения «Федеральное управление по безопасному хранению и уничтожению химического оружия при Министерстве промышленности и торговли Российской Федерации (войсковая часть 70855) - 1206 объект по хранению и уничтожению химического оружия (войсковая часть 21222)», Россия, Пензенская область, п. Леонидовка, т. 89063994748, e-mail:mi_andreeva@bk.ru

Объектами исследований являлись пробы почв и травянистых растений, отобранные в лесных экосистемах Пензенской области, которые анализировались на валовое содержание кадмия методом атомно-адсорбционной спектрометрии. Было установлено, что в образцах, отобранных из горизонтов А различных разновидностей серых лесных почв, содержание данного элемента в 4-5 раз ниже ориентировочно допустимых концентраций (ОДК). Концентрация кадмия в изученных видах растений также была значительно ниже предельно допустимых концентраций (ПДК). Для трав было зафиксировано два типа распределения кадмия. У сныти обыкновенной его содержание было более высоким в подземных органах, а у осоки волосистой - в листьях. Минимальные значения были определены для репродуктивных органов. Содержание кадмия в вегетативных органах, представителей различных хозяйственных групп кормовых растений было различным. Наименьшими значениями оно выражалось у представителей семейства бобовых. Средние значения определены для видов разнотравья, максимальные - для злаков. Пробы биоматериала различных видов растений, отобранных в районе исследований и используемых в качестве пищевого и лекарственного сырья, содержали различное количество изучаемого элемента. Минимальные значения были определены для шишек ольхи, ягод малины и земляники, максимальные - для листьев и плодов черники. Таким образом, заготавливаемые в районе исследований кормовые, лекарственные и пищевые растения безопасны в отношении содержания кадмия.

Ключевые слова: загрязнение, кадмий, кормовые травы, лекарственные растения, ягоды.

\section{Введение}

Одним из важнейших требований к дикорастущим кормовым, лекарственным и пищевым растениям является содержание в них тяжелых металлов в пределах установленных нормативов. Среди них особое место занимает кадмий, соединения которого обладают высокой токсичностью как для растений, так для животных и человека [10, 14, 22-24,].

Содержание тяжелых металлов в растениях зависит, как от биологических особенностей видов, так и от условий их местообитания. Этой проблеме посвящено достаточно большое количество публикаций [17]. Однако, имеющиеся данные не охватывают всей территории страны, а характеризуют ситуацию лишь в отдельных ее частях $[1,7,8,20]$. То есть проблема загрязнения тяжелыми металлами дико- растущих кормовых, лекарственных и пищевых растений имеет региональные особенности. Она приобретает особую актуальность в тех областях страны, где подобные исследования ранее не проводились. Это определило цель данной работы: изучить закономерности накопления кадмия дикорастущими кормовыми, лекарственными и пищевыми растениями на серых лесных почвах в условиях Пензенской области.

\section{Методы и материалы}

Пензенская область располагается в лесостепной зоне европейской части России в 600 км к юго-востоку от г. Москва. Ее растительный покров имеет типичный лесостепной облик. Лесистость территории составляет 20,5\% [5].

Объектами исследований являлись пробы почв и травянистых растений, ото- 


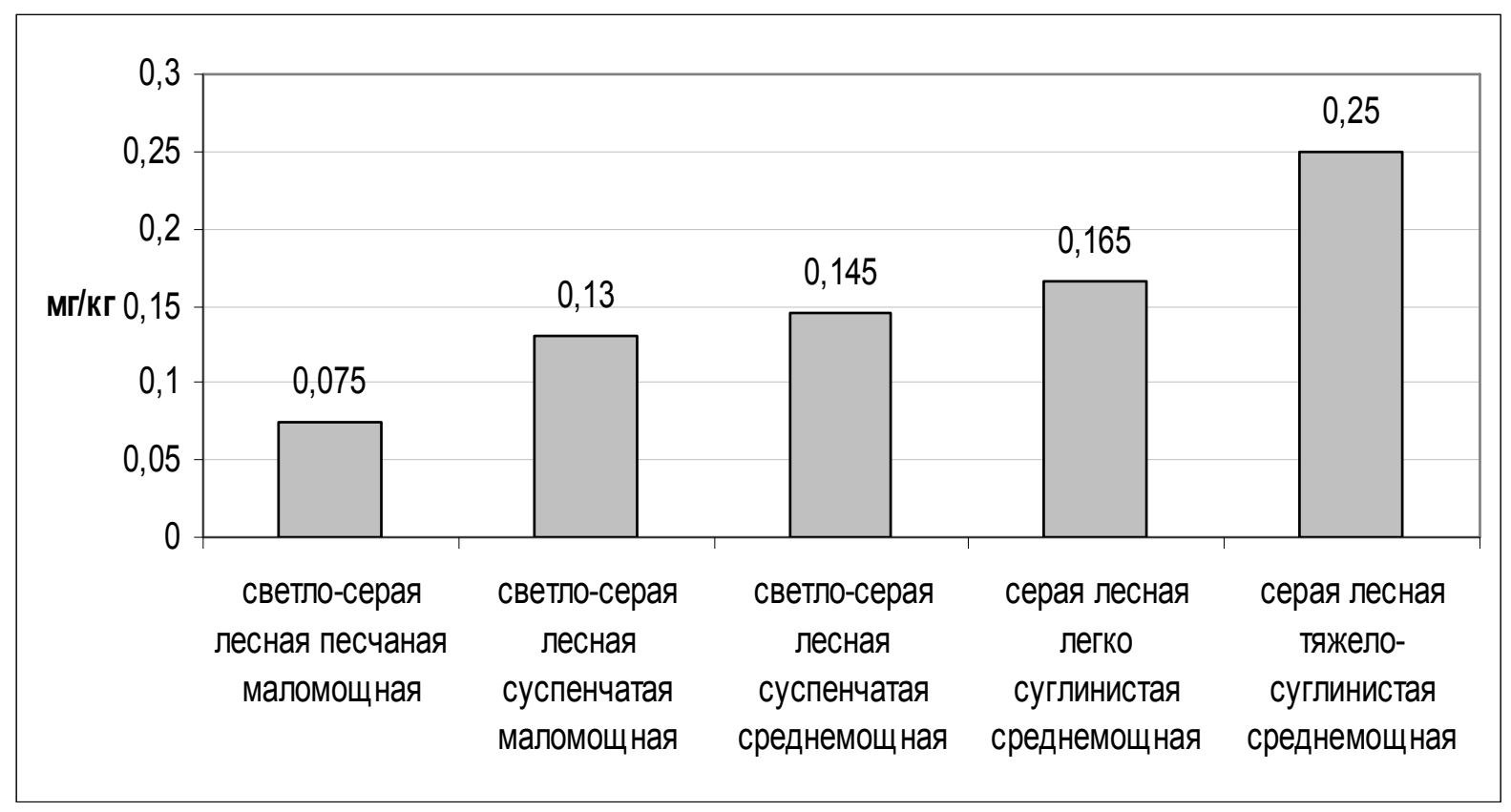

Содержание кадмия в горизонте А различных разновидностях серых лесных почв, мг/к己

бранные в лесных экосистемах Пензенской области, которые анализировались на валовое содержание кадмия. Исследования проводились с сентября 2015 по июнь 2019 г. Пробы почв и биоматериала растений отбирались в Городищенском, Кузнецком, Лунинском, Никольском, Пензенском и Шемышейском районах.

Определение растений осуществлялось по определителю «Флора средней полосы европейской части России» [12]. Русские и латинские названия в статье даются в соответствии с этим руководством.

Анализ образцов почв и биоматериала выполнялся на атомно-адсорбционном спектрометре МГА-915 МД. Лабораторные исследования осуществлялись на базе научно-исследовательской лаборатории филиала ФБУ «Федеральное управление по безопасному хранению и уничтожению химического оружия при Министерстве промышленности и торговли РФ» (войсковая часть 70855) - 1206 объект по хранению и уничтожению химического оружия (войсковая часть 21222).

Для количественной оценки способности накапливать кадмий растениями нами рассчитывался такой показатель, как коэффициент накопления (КН), представляющий собой отношение содержания элемента в организме к его содержанию в почве. Если КН оказывается выше 1, то есть концентрация химического элемента в растении превышает таковую в почве, значит объект является биоконцентратором.

\section{Результаты}

Первым этапом исследований было изучения содержания кадмия в почвах в местах произрастания кормовых, лекарственных и пищевых растений. Как показал анализ образцов, отобранных из горизонтов А различных разновидностей серых лесных почв, содержание в них кадмия в 45 раз ниже установленных ОДК [4]. По валовому содержанию данного металла рассматриваемые почвенные разновидности отличаются друг от друга. Минимальное содержание рассматриваемого элемента характерно для почв легкого механического состава, максимальное - для тяжелых суглинистых почв. Однако, эта разница не существенна. Максимальный показатель превышает минимальный всего в 3,3 раза (рисунок).

Это связано с тем, что суглинистые почвы обладают более высокой способностью поглощать и удерживать анионы и катионы, т. к. коллоидные частицы, от которых зависит поглотительная способность, в песчаных и супесчаных составляют всего 1-5\%, а в глинистых почвах от 20 до $40 \%$ (рисунок). Кроме того, поглотительная способность почв практически всегда положительно связана с концентрацией гумуса в почве, что обусловлено коллоидными составами гумуса, по содержанию которого суглинистые почвы также существенно превосходят супеси [9] (рисунок).

Описанная закономерность учитывается и при нормировании содержания рассматриваемого элемента в почвах. Для суглинитстых почв ОДК кадмия в 2 раза выше, чем для супесчаных [4]. 
Содержание кадмия в травянистых растениях, растущих под пологом леса в мә/кг и КН 0.145

\begin{tabular}{|l|c|c|c|c|c|}
\hline \multicolumn{1}{|c|}{ Вид растений } & \multicolumn{4}{|c|}{ Содержание кадмия, мг/кг } & \multirow{2}{*}{ КН } \\
\cline { 2 - 5 } & Листья & Корневища & $\begin{array}{c}\text { Вегетативные } \\
\text { органы }\end{array}$ & Цветки & \\
\hline $\begin{array}{l}\text { Ocoка волосистая } \\
\text { (Carex pilosa) }\end{array}$ & $0,0263 \pm 0,0079$ & $0,0037 \pm 0,0011$ & $0,0150 \pm 0,0045$ & $0,0020 \pm 0,0006$ & 0,055 \\
\hline $\begin{array}{l}\text { Cныть обыкновенная } \\
\text { (Аеgородіum pоdagrári }\end{array}$ & $0,0053 \pm 0,0016$ & $0,0076 \pm 0,0023$ & $0,0064 \pm 0,0013$ & $0,0013 \pm 0,0004$ & 0.029 \\
\hline Средний показатель & 0,0098 & 0,0043 & 0,0071 & 0,0030 & 0,048 \\
\hline
\end{tabular}

Среднее содержание кадмия для изученных в ходе исследований почв было низким и составило $0,153 \mathrm{мг/кг.} \mathrm{Оно} \mathrm{оказы-}$ вается в 3,3 раза ниже, чем в почвах мира; в 2,8 раза - чем в западных районах европейской части России и в 2,5 раза ниже, чем в почвах Семипалатинского Прииртышья [3, 11, 18, 21]. Главной причиной этого является то, что рассматриваемые почвы формируются на осадочных породах, которые бедны кадмием. Как показали результаты измерений, в песчаных породах содержание данного металла в районе исследований было ниже среднего показателя для песчаников в 1,9 раза, а в бескарбонатных глинах ниже среднего показателя для глин в 7,7 раза [3].

Кроме подстилающих пород источником загрязнения кадмием являются атмосферные выпадения. Содержание кадмия в них связано с расстоянием от источников загрязнения. Установлено, что загрязнение осадков кадмием в условиях европейской части России уменьшается с запада на восток по мере удаления от промышленных районов зарубежной Европы. Пензенская же область удалена от них на расстояние более 1,5 тыс. км. Кроме того, на ее территории и в сопредельных регионах отсутствуют крупные источники загрязнения: ТЭС, работающие на угле, предприятия металлургической и химической промышленности. В связи с этим техногенное загрязнение, в силу особенностей экономико-географического положения Пензенской области, не вносит существенных изменений в фоновое содержание кадмия ее почвенного покрова.

В ходе исследований нами изучались закономерности накопления $\mathrm{Cd}$ наиболее распространенными видами травянистых растений, поедаемых домашними животными при выпасе под пологом леса - осоки волосистой и сныти обыкновенной. Как показали результаты измерений, изученные виды трав не являются накопителями $\mathrm{Cd}$. Рассчитанные КН у них значительно меньше 1 (табл. 1).
Для изученных видов трав было зафиксировано два типа распределения кадмия. У сныти обыкновенной его содержание было более высоким в подземных органах, а у осоки волосистой - в листьях. Вероятно, характер распределения данного металла в организме растений зависит от фризиологических особенностей отдельных видов. Это согласуется с опубликованными результатами других исследователей, которые также отмечают оба вида распределения [16].

В репродуктивных органах изученных видов трав содержание кадмия выражается меньшими значениями, чем в вегетативных. В цветках осоки волосистой концентрация рассматриваемого элемента была ниже в 7,5 раза, а у сныти обыкновенной всего в 3,3 раза. Вероятно это общая закономерность, т. к. на нее указывают и другие авторы [6].

Содержание кадмия в растениях подвержено сезонной динамике. У изученных видов наблюдалось существенное возрастание содержания кадмия в надземных органах в течение вегетационного периода. У осоки волосистой с апреля до сентября оно выросло в 2,08 раза, а у сныти обыкновенной в 23 раза.

В ходе исследований нами была дана оценка содержания кадмия в луговых травах. В качестве объектов исследования были использованы наиболее распространенные виды опушек и лесных полян, на которые приходится до 90 \% массы травостоев луговых сообществ и, соответственно, массы заготавливаемого сена. Содержание кадмия определялось в надземной части растений в период цветения, т. е. в третье декаде июня, когда происходит заготовка кормов.

Как показывает сравнение содержания кадмия в вегетативных органах представителей различных хозяйственных групп было различным. Наименьшими значениями оно выражалось у представителей семейства бобовых. Средние значения были определены для видов разнотравья, макси- 
Содержание кадмия в травянистых растениях, лесных сенокосов, мә/кг и КН

\begin{tabular}{|l|c|c|}
\hline \multicolumn{1}{|c|}{ Виды растений } & $\begin{array}{c}\text { Содержание } \\
\text { кадмия, мг/кг }\end{array}$ & КН \\
\hline 3лаки & $\mathbf{0 , 0 6 0}$ & $\mathbf{0 , 3 4 2}$ \\
\hline Ежа сборная (Dactylis glomerata) & $0,091 \pm 0.027$ & 0,551 \\
\hline Кострец береговой (Bromopsis riparia) & $0,033 \pm 0,010$ & 0,188 \\
\hline Лисохвост луговой (Alopecúrus praténsis) & $0,057 \pm 0,017$ & 0,325 \\
\hline Полевица тонкая (Agrostis capillaris) & $0,038 \pm 0.011$ & 0,584 \\
\hline Тимофеевка луговая (Phleum pratense) & $0,081 \pm 0,024$ & 0,490 \\
\hline Бобовые & $\mathbf{0 , 0 1 0}$ & $\mathbf{0 , 0 5 7}$ \\
\hline Астрагал нутовый (Astragálus cícer & $0,007 \pm 0.002$ & 0,028 \\
\hline Клевер горный (Trifolium montanum) & $0,011 \pm 0,003$ & 0,062 \\
\hline Клевер луговой (Trifolium pratense) & $0,019 \pm 0.006$ & 0,115 \\
\hline Люцерна серповидная (Medicago falcata) & $0.004 \pm 0.001$ & 0,024 \\
\hline Лядвенец рогатый (Lotus corniculatus) & $0.009 \pm 0,003$ & 0,051 \\
\hline Разнотравье & $\mathbf{0 , 0 1 4}$ & $\mathbf{0 , 0 8 4}$ \\
\hline Лабазник шестилепестный (Filipendula vulgaris) & $0,005 \pm 0,002$ & 0,028 \\
\hline Нивяник обыкновенный (Leucanthemum vulgare) & $0,002 \pm 0,001$ & 0,011 \\
\hline Подмаренник настоящий (Galium verum) & $0,052 \pm 0.016$ & 0,315 \\
\hline Смолка клейкая Viscária vulgáris & $0,002 \pm 0,001$ & 0,011 \\
\hline Репешок аптечный (Agrimonia eupatoria) & $0,008 \pm 0.002$ & 0,055 \\
\hline Средний показатель для травянистых растений & $\mathbf{0 . 0 3 3}$ & $\mathbf{0 . 3 5 7}$ \\
\hline ПДК в растительных кормах для ceльскохозяйственных животных & 0,3 & \\
\hline
\end{tabular}

мальные - для злаков (табл. 3). Полученные данные согласуются с результатами других исследователей [16]. Не смотря на указанные различия, все полученные значения оказались ниже ПДК содержания кадмия в растительных кормах для сельскохозяйственных животных (табл. 2).

В настоящее время, несмотря на производство широчайшего спектра синтетических фрармакологических препаратов, потребность в дикорастущем лекарственном сырье не снижается. Одним из важнейших требований к его качеству является содержание в нем токсичных элементов в пределах установленных нормативов.

Экспертиза дикорастущего пищевого и лекарственного сырья предполагает определение в нем содержания кадмия как опасного токсичного элемента. Как показали результаты измерений, пробы биоматериала различных видов растений, отобранных в районе исследований и используемых в качестве пищевого и лекарственного сырья, содержали различное количество изучаемого элемента (табл. 3). Минимальные значения были определены для шишек ольхи, ягод малины и земляники, максимальные - для листьев и плодов черники. Полученные данные сопоставимы с результатами измерений других исследователей [1, 7]. Так, С. Б. Сосорова с соавторами [19] так же указывают на более высокое содержание кадмия в чернике обыкновенной, по сравнению с другими видами лекарственных и пищевых дикоросов.
Несмотря на указанные различия в содержании кадмия в дикорастущем лекарственном сырье, все определенные значения лежали в пределах ПДК для плодов, ягод и БАД на растительной основе и чаев, произведенных в России $[17,18]$. Эти нормативы нами использовались в связи отсутствием регламента по содержанию токсичных элементов в лекарственном растительном сырье.

Некоторые виды, применяемые в качестве лекарственного сырья, используются и как пищевые растения. Это земляника лесная, малина обыкновенная и черника. В связи с тем, что они потребляются в значительно большем количестве, чем лекарственные формы и при том в свежем виде, для них установлены более жесткие ПДК, чем для лекарственного сырья [13]. Как показали результаты измерений пробы дикорастущих ягод, отобранные на территории района исследований, содержали кадмий в количествах, лежащих далеко за пределами ПДК.

Таким образом, заготавливаемые в районе исследований кормовые, лекарственные и пищевые растения безопасны в отношении содержания кадмия.

\section{Заключение}

Невысокие концентрации кадмия в осадочных породах и отсутствие крупных источников загрязнения определяют низкое содержание рассматриваемого элемента в серых лесных почвах Пензенской области. Поэтому сено, а также лекарственное и пи 
Таблица 3

Содержание кадмия в дикорастущем пищевом и лекарственном сырье мә/кә и КН

\begin{tabular}{|l|c|c|}
\hline \multicolumn{1}{|c|}{ Вид растений } & $\begin{array}{c}\text { Содержание кадмия, } \\
\text { мг/кг }\end{array}$ & КН \\
\hline Душица обыкновенная Origanum vulgare (соцветия) & $0,0039 \pm 0,0012$ & 0,0268 \\
\hline Земляника лесная Fragaria vesca (плоды) & $0,0014 \pm 0,0004$ & 0,0096 \\
\hline Малина обыкновенная Rubus idáeus (плоды) & $0,0011 \pm 0,0003$ & 0,0075 \\
\hline Ольха клейкая Alnus glutinosa (шишки) & $0,0010 \pm 0,0003$ & 0,0068 \\
\hline Роза собачья Rosa canina (плоды) & $0,0010 \pm 0,0003$ & 0,0068 \\
\hline Черника обыкновенная Vaccinium myrtillus (лист) & $0,0090 \pm 0,0027$ & 0,0620 \\
\hline Черника обыкновенная Vaccínium myrtillus (плоды) & $0,0090 \pm 0,0027$ & 0,0620 \\
\hline Цмин песчаный Неlichrysum arenarium (соцветия) & $0,0028 \pm 0,0008$ & 0,0193 \\
\hline Средний показатель & 0,0041 & 0,0284 \\
\hline ПДК для плодов и ягод & 0,03 & \\
\hline ПДК для БАД на растительной основе & 1,0000 & \\
\hline
\end{tabular}

щевое растительное сырье, заготовка которого возможно в изучаемых лесных сообществах, безопасно в отношении содержания кадмия. Все определенные значения лежали далеко за пределами ПДК. В тоже время было установлено, что при одинаковых фоновых концентрациях кадмия в почве, в зеленой массе растений различных хозяйственных групп его содержание было разным. Наименьшими значениями оно выражалось у представителей семейства бо- бовых. Средние значения были определены для видов разнотравья, максимальные для злаков. Изученные виды лекарственных растений также отличались по содержанию кадмия. Минимальные значения были определены для шишек ольхи, ягод малины и земляники, максимальные - для листьев и плодов черники. Таким образом, интенсивность накопления рассматриваемого элемента в первую очередь зависит от биологических особенностей отдельных видов.

\section{Лuтература}

1. Афранасьева, Л. В., Содержание микроэлементов в растениях Vaccinium uliginosum L., произрастающих в Южном Прибайкалье / Л. В. Афранасьева, В. К. Кашин // Химия растительного сырья. 2013. - № 2. - C. 195-200.

2. ВетПин 13-5-01/0101. Ветеринарные правила и нормы по безопасности кормов, кормовых добавок и сырья для производства кормов. - [Электронный ресурс] vitmuca. ru (дата обращения 11.08.2019).

3. Виноградов, А. П. Среднее содержание химических элементов в главных типах изверженных горных пород земной коры/ А. П. Виноградов // Геохимия. - 1962. - № 7. - С. 555-571.

4. ГОСТ 17.4.1.02-83. Охрана природы. Почвы. Классификация химических веществ для контроля загрязнения. - Москва, - 1983. - 9 с.

5. Иванов, А. И. Природные условия Пензенской области: современное состояние. Том 1. Геологическая среда, рельеф, климат, поверхностные воды, почвы, растительный покров: монография. / А. И. Иванов, Н. В. Чернышов, Е. Н. Кузин. - Пенза: РИО ПГАУ, 2017. - 236 с.

6. Еськов, Е. К. Аккумуляция тяжёлых металлов в теле пчел / Е. К. Еськов, Г. С. Ярошевич, М. Д. Еськова // Пчеловодство. - 2008. - № 2. - С. 14-16.

7. Кашин, В.К. Микроэлементный состав некоторых лекарственных растений Забайкалья / В. К. Кашин // Растительные ресурсы. - 2010. - Вып. 3. - С. 73-85.

8. Келимханова, С. Е. Микроэлементный состав лекарственного растительного сырья - как показатель его качества / С. Е. Келимханова С. Е., А. Е. Баелова А. С. Кожамжанова // Вестник КазНМУ им. С. Д. Ассрендиарова. - 2010. Вып. 3. - № 5. - С. 219-221.

9. Ковда В. А. Почвоведение / В. А. Ковда, Б. Г. Розанов, Г. Д. Белицина, В. Д. Василевская, Л. А. Гр10ишина - М.: Высш. шк. - 1988. -400 с.

10. Кривошеев, А. Б. Токсическое действие кадмия на организм человека. / А. Б. Кривошеев, Е. Л. Потеряева, Б. Н. Кривошеев, Л. Я. Куприянова, Е. Л. Смирнова // Медицина труда и промышленная экология. - 2012. - № 6. - С.35-42.

11. Лукин, С. В. Микроэлементы в почвах Белгородской области / С. В. Лукин, П. М. Авраменко // Земледелие. - 2008. - № 7. - С. 21-22.

12. Маевский, П. Ф. Флора средней полосы европейской части России / П. Ф. Маевский. - 11-е изд. - М.: Товарищество научных изданий КМК. - 2014. - 635 с.

13. МУК 4.1.1501-03 Инверсионно-вольтамперометрическое измерение концентрации цинка, кадмия, свинца и меди в пищевых продуктах и продовольственном сырье - (дата обращения 11.08.2019).

14. Островская, С. С. Токсические Эффректы кадмия / С. С. Островская // Вісник проблем біологіі і медіцины. - 2014. - Т.3. - Вып.2. - С. 33 - 35.

Нива Поволжья $\quad$ № 4 (53) ноябрь 2019 
15. СанПин 2.3.2.560-96. Гигиенические требования к качеству и безопасности продовольственного сырья и пищевых продуктов. - Москва, - 1996. [Электронный pecypc]. docs. cntd. ru>9052436 (дата обращения 11.08.2019).

16. СанПин 2.3.2.1078-01. Гигиенические требования к безопасности и пищевой ценности пищевых продуктов. - Москва, 2001. [Электронный ресурс]. docs. cntd. ru>2,3.2.1078-01(дата обращения 11.08.2019).

17. Сосорова, С. Б. Содержание микроэлементов в лекарственных растениях / С. Б. Сосорова, М. Г. Меркушева, Л. Л. Убугунов // Химия растительного сырья. - 2016. - № 2. - С. 53-59.

18. Пильгук, О. Н.. Экологическая оценка состояния кадмия в системе почва-растение в условиях Семипалатинского Прииртышья / О. Н. Пильгук Автореф. дис. канд. биол. наук. - Семипалатинск, - 2005. - 22 с.

19. Романькова, А. А. Содержание кадмия и свинца в высших растениях на территории Красненского района Белогородской области / А. А. Романькова, И. В. Балтуцкая // Научные ведомости. Серия Естественные науки. - 2011. - Вып.16. - № 3 - С. 68-75.

20. Цапалова, И. Э. Экспертиза дикорастущих плодов и ягод / И. Э. Цапалова, М. Д. Губина, О. В. Голуб, В. М. Поздняковский - Новосибирск: Сибирское университетское издательство, 2005. $-201 \mathrm{c}$.

21. Четверикова, Н. С., Кадмий а агроландшафтах лесостепной зоны / Н. С. Четверикова, Л. В. Марциневская // Достижения науки и техники в АПК. - 2013. - № 7. - С. 69-70.

22. Chugh, L. K. Effect of cadmium on activities of some enzymes of glycolysis and pentose phosphate pathway in pea / L. K. Chugh, S. K. Sawhney // Biol. Plant. 1999. - V. 42. - N 3. P. 401-407.

23. Ci, D. Cadmium stress in wheat seedlings: growth, cadmium accumulation and photosynthesis / D. Ci, D. Jiang, B. Wollenweber // Acta Physiol. Plant. - 2010. - V. 32. - N 6. - P. 365-373.

24. Clemens, S. Toxic metal accumulation, responses to exposure and mechanisms of tolerance in plants / S. Clemens // Biochemie. - 2006. - V. 88. - N 4. - P. 1707-1719.

\section{UDC 614.31:635:546.8}

DOI: $10.36461 /$ NP.2019.52.3.002

\section{ABOUT THE CONTENT OF CADMIUM IN WILD-GROWING FODDER, MEDICINAL, AND FOOD PLANTS OF FORESTS OF THE PENZA REGION}

\section{A. I. Ivanov, Doctor of Biological Sciences, professor}

Penza State Agrarian University, Russia, t. 896563331761. e-mail: rcgkim@mail.ru

\section{I. Andreeva, research worker}

A branch of the federal budgetary institution «Federal Office for the Safe Storage and Destruction of Chemical Weapons under the Ministry of Industry and Trade of the Russian Federation (military unit 70855) - 1206 facility for storage and destruction of chemical weapons (military unit 21222)», Leonidovka village, Penza region, Russia, t. 89063994748, e-mail: mi_andreeva@bk.ru

The objects of the research were samples of soils and herbaceous plants taken in the forest ecosystems of the Penza region, which were analyzed for the total content of cadmium by atomic absorption spectrometry. It was found that in the samples taken from A-horizons of different varieties of gray forest soils, the content of this element was 4-5 times lower than the approximate permissible concentrations (APC). The cadmium concentration in the studied plant species was also significantly lower than the maximum permissible concentrations (MPC). Two types of cadmium distribution were recorded fro herbs. In the goatweed, its content was higher in the underground organs, and in the carex - in the leaves. The minimal values were determined for reproductive organs. The cadmium content in the vegetative organs - representatives of various economic groups of feed plants was different. The lowest values were expressed among representatives of the legume family. The average values are determined for species of herbs, the maximum - for cereals. The samples of the biomaterial of various plant species taken in the study area and used as food and medicinal raw materials contained various amounts of the studied element. The minimum values were determined for alder cones, raspberries and strawberries, the maximum - for leaves and blueberries. Thus, fodder, medicinal and food plants procured in the research area were safe for cadmium content.

Key words: pollution, cadmium, grasses, medicinal plants, berries. 


\section{References:}

1. Afanasyeva, L. V., The content of microelements in plants of Vaccinium uliginosum L., growing in the Southern Baikal region / L. V. Afanasyeva, V. K. Kashin // Khimija Rastitel'nogo Syr'ja. - 2013. No. 2. - p. 195-200.

2. VetPin 13-5-01 / 0101. Veterinary rules and regulations for the safety of fodders, fodder additives and raw materials for fodder production. - [Electronic resource] vitmuca. ru (accessed August 11, 2019).

3. Vinogradov, A. P. The average content of chemical elements in the main types of igneous rocks of the earth's crust / A. P. Vinogradov // Geochemistry. - 1962. - No. 7. - p. 555-571.

4. GOST 17.4.1.02-83. Protection of Nature. The soil. Chemical classification for pollution control. - Moscow, - 1983. - 9 p.

5. Ivanov, A. I. Natural conditions of the Penza region: current state. Volume 1. Geological environment, relief, climate, surface water, soil, vegetation: monograph. / A. I. Ivanov, N. V. Chernyshov, E. N. Kuzin. - Penza: RIO PSAU, 2017.-- 236 p.

6. Yeskov, E. K. Accumulation of heavy metals in the body of bees / E. K. Yeskov, G. S. Yaroshevich, M. D. Yeskova // Beekeeping. - 2008. - No. 2. - 3. 14-16.

7. Kashin, V. K. The microelement composition of some medicinal plants of Transbaikalia / V. K. Kashin // Rastitelnye Resursy. - 2010. - Issue. 3. - p. 73-85.

8. Kelimkhanova, S. E. Microelement composition of medicinal plant material as an indicator of its quality / S. E. Kelimkhanova, A. E. Baelova, A. S. Kozhamzhanov // Bulletin of KazSMU named after S. D. Asfendiarov. - 2010. Issue. 3. - No. 5. - p. 219-221.

9. Kovda V. A. Soil Science / V. A. Kovda, B. G. Rozanov, G. D. Belitsina, V. D. Vasilevskaya, L. A. Grishina - M.: Vysshaya shkola - 1988. - 400 p.

10. Krivosheev, A. B. The toxic effect of cadmium on the human body / A. B. Krivosheev, E. L. Poteryaeva, B. N. Krivosheev, L. Ya. Kupriyanova, E. L. Smirnova // Russian Journal of Occupational Health and Industrial Ecology. - 2012. - No. 6. - P.35-42.

11. Lukin, S. V., Microelements in the soils of the Belgorod region / S. V. Lukin, P. M. Avramenko // Zemledeliye. - 2008. - No. 7. - p. 21-22.

12. Mayevsky, P. F. Flora of the central European part of Russia / P. F. Mayevsky. - 11th ed. - M.: Partnership of scientific publications of KMK. - 2014.-- 635 p.

13. MUK 4.1.1501-03 Inversion-voltammetric measurement of the concentration of zinc, cadmium, lead and copper in food products and food raw materials - (accessed 11.08.2019).

14. Ostrovskaya, S. S. Toxic Effects of Cadmium / S. S. Ostrovskaya // Bulletin of problems of biology and medicine. - 2014. - V.3. - Issue 2. - p. 33 - 35.

15. SanPin 2.3.2.560-96. Hygienic requirements for the quality and safety of food raw materials and food products. - Moscow, - 1996. - [Electronic resource]. docs. cntd. ru> 9052436 (accessed 08.08.2019).

16. SanPin 2.3.2.1078-01. Hygienic requirements for food safety and nutritional value. - Moscow, 2001. - [Electronic resource]. docs. cntd. ru> 2,3.2.1078-01 (accessed 08.08.2019).

17. Sosorova, S. B. The content of microelements in medicinal plants / S. B. Sosorova, M. G. Merkusheva, L. L. Ubugunov // Khimija Rastitel'nogo Syr'ja. - 2016. - No. 2. - p. 53-59.

18. Pilguk, O. N. Ecological assessment of the state of cadmium in the soil-plant system under the conditions of the Semipalatinsk Irtysh / O. N. Pilguk Abstract of a thesis of Cand. biol. sciences. Semipalatinsk, - 2005. - 22 p.

19. Romankova, A. A. The content of cadmium and lead in higher plants on the territory of the Krasnensky district of the Belgorod region / A. A. Romankova, I. V. Baltutskaya // Nauchniye Vedomosti. Series Natural Sciences. - 2011. - Issue 16. - No. 3 - p. 68-75.

20. Tsapalova, I. E. Examination of wild fruits and berries / I. E. Tsapalova, M. D. Gubina, O. V. Golub, V. M. Pozdnyakovsky - Novosibirsk: Siberian University Press, 2005. - 201 p.

21. Chetverikova, N. S., Cadmium and agrolandscapes of the forest-steppe zone / N. S. Chetverikova, L. V. Marcinevskaya // Achievements of science and technology in the agricultural sector. 2013. - No. 7. - p. 69-70.

22. Chugh, L. K. Effect of cadmium on activities of some enzymes of glycolysis and pentose phosphate pathway in pea / L. K. Chugh, S. K. Sawhney // Biol. Plant. 1999. - V. 42. - N 3. P. 401407.

23. Ci, D., Cadmium stress in wheat seedlings: growth, cadmium accumulation and photosynthesis / D. Ci, D. Jiang, B. Wollenweber // Acta Physiol. Plant. - 2010. - V. 32. - N 6. - P. 365-373.

24. Clemens, S. Toxic metal accumulation, responses to exposure and mechanisms of tolerance in plants / S. Clemens // Biochemie. - 2006. - V. 88. - N 4. - P. 1707-1719. 